\section{Literatur}

ANDRASSY I. (1984): Klasse Nematoda (Ordnungen Monhysterida, Desmoscolecida, Araeolaimida, Chromadorida, Rhabditida). Gustav Fischer Verlag, Stuttgart

Bonciers T. (1988): De Nematoden van Nederland. Natuurhistorische Bibliotheek van de KNNV, Utrecht

Debus R., Hund K. (1995): Entwicklung analytischer Methoden zur Erfassung biologisch relevanter Belastungen von Böden. Statusseminar zum Förderschwerpunkt "Ökotoxikologie“ des BMBF 2/95: 215-225

DONKIN S.G., DUSENBERY D.B. (1993): A soil toxicity test using the nematode Caenorhabditis elegans and an effective method of recovery. Archives of Environmental Contamination and Toxicology 25: $145-151$

DONKIN S.G., DUSENBERY D.B. (1994): Using the Caenorhabditis elegans soil toxicity test to identify factors affecting toxicity of four metal ions in intact soil. Water Air \& Soil Pollution 78: 359-373

FREY F. (1976): Untersuchungen über die Wirkungen von im Obstbau verwendeten Herbiziden auf den Testnematoden Acrobeloides buetschlii (de Man, 1884) Steiner und Buhrer, 1933. Zeitschrift für Pflanzenkrankheiten und Pflanzenschutz 83: 434-441

GILBERTSON M. (1989): Effects on fish and wildlife populations. In: R. KIMBrough \& A.A. JeNSEN (eds.) Halogenated biphenyls, terphenyls, naphthalenes, dibenzodioxins and related products. Elsevier Science Publ., pp. 103-127

Guven K., Duce J.A., De Pomerai D.I. (1994): Evaluation of a stressinducible transgenic nematode strain for a rapid aquatic toxicity testing. Aquatic Toxicology 29: 119-137

Haight M., Mudry T., Pasternak J. (1982): Toxicity of seven heavy metals on Panagrellus silusiae: the efficacy of the free-living nematode as an in vivo toxicological bioassay. Nematologica 28: 1-11

HFIMBACH F. (1985): Comparison of laboratory methods, using Eisenia foetida and Lumbricus terrestris, for the assessment of the hazard of chemicals to earthworms. Zeitschrift für Pflanzenkrankheiten und Pflanzenschutz 92: 156

HoY J.B. (1990): Long-term effects of lindane on the oribatid community in a pine plantation. Environmental Entomology 19: 898-900

KammenGa J.E., VAN Gestel C.A.M., Bakkfr J. (1994): Patterns of sensitivity to cadmium and pentachlorophenol among nematode species from different taxonomic and ecological groups. Archives of Environmental Contamination and Toxicology 27: 88-94

KORDEL W., WAHLE U. (1995): Methoden zur Erfassung biologisch relevanter Belastungen von Böden - Extraktion und chemische Analytik biologisch relevanter Belastungen. Abschlußbericht, Förderschwerpunkt Ökotoxikologie des BMFT, eingereicht.

Macek K.J., Buxton K.S., Derr S.K., Dean J.W., Sauter S. (1976): Chronic toxicity of lindane to selected aquatic invertebrates and fish. Washington D.C., US-EPA Ecological Research Series EPA600/3-76-046

MAYer F.L., Mehrle P.M., SANDERS H.O. (1977): Residue dynamics and biological effects of polychlorinated biphenyls in aquatic organisms. Archives of Environmental Contamination and Toxicology 5: 501-511

NICHOLAS W.L. (1975): The biology of free-living nematodes. Clarendon Press, Oxford

Pagano G., Cipollaro M., Corsale G., Esposito A., Ragucci E., Giordano G.G., TriefF N.M. (1985): Comparative toxicities of chlorinated biphenyls on sea urchin egg fertilisation and embryogenesis. Marine Environmental Research 17: 240-244
Parmfile R.W., Wentshi. R.S., Phillips C.T., Simini M., Checkat R.T. (1994): Soil microcosm for testing the effects of chemical pollutants on soil fauna communities and trophic structure. Environmental Toxicology and Chemistry 12: 1477-1486

POPHAM J.D., WEBSTER J.M. (1982): Ultrastructural changes in Caenorhabditis elegans (Nematoda) caused by toxic levels of mercury and silver. Ecotoxicology and Environmental Safety 6: 183-189

SAFE S. (1992): Toxicology, structure-function relationship, and human and environmental health impacts of polychlorinated biphenyls: progress and problems. Environmental Health Perspectives 100: 259-268

SAMOILOFF M.R. (1990): The nematode toxicity assay using Panagrellus redivivus. Biological Assessment 5: 309-318

Slooff W., Canton J.H., Hermens J.L.M. (1983): Comparison of the susceptibility of 22 freshwater species to 15 chemical compounds. I. (Sub)acute toxicity tests. Aquatic Toxicology 4: 113-128

SMITH V.L., JOHNSTON P.A. (1992): Differential haemotoxic effect of PCB congeners in the common shrimp, Crangon crangon. Comparative Biochemistry and Physiology 101 C: 641-649

Stalling D.L., MAYER F.L. jr. (1972): Toxicities of PCBs to fish and environmental residues. Environmental Health Perspectives 1: $159-164$

STRINGHAM E.G., CANDido E.P.M. (1994): Transgenic hsp16-lacZ strains of the soil nematode Caenorhabditis elegans as biological monitors on environmental stress. Environmental Toxicology and Chemistry 13: 1211-1220

Sunhaus W. (1976): Vergleichende Untersuchungen zur Phylogenie, Systematik, Ökologie, Biologie und Ethologie der Rhabditidae (Nematoda). Zoologica 43: 1-229

Thurston R.V., Gilfoil. T.A., Meyn E.L., Zajili. R.K., Aoki T.I., Veith G.D. (1985): Comparative toxicity of ten organic chemicals to ten common aquatic species. Water Research 19: 1145-1155

Ville P., Roch P., Cooper E.L., Masson P., Narbonne J.F. (1995): PCBs increase molecular-related activities (lysozyme, antibacterial, hemolysis, proteases) but inhibit macrophage-related functions (phagocytosis, wound healing) in earthworms. Journal of Invertebrate Pathology 65: 217-224

WASILEWSKA L. (1989): Impact of human activities on nematode communities in terrestrial ecosystems. In: B. ClarhOLM \& L. BERGSTROM (eds.) Ecology of Arable Land - Perspectives and Challenges. Kluwer Acad. Publ., Dordrecht, pp. 123-132

WHO (1991): Environmental Health Criteria 124: Lindane. World Health Organization, Geneva

Williams P.L., Dusenkery D.B. (1988): Using the nematode Caenorhabditis elegans to predict mammalian acute lethality to metallic salts. Toxicology and Industrial Health 4: 469-478

Williams P.L., Dusenbery D.B. (1990): Aquatic toxicity testing using the nematode, Caenorbabditis elegans. Environmental Toxicology and Chemistry 9: 1285-1290

WILMS W. (1992): Prüfung der Auswirkungen von Pflanzenschutzmitteln auf räuberische Nematoden. Nachrichtenblatt des Deutschen Pflanzenschutzdienstes 44: 25-29

Yeates G.W., Bongers T., De Goede R.G.M., Freckman D.W., GeorGIEVA S.S. (1993): Feeding habits in nematode families and genera - an outline for soil ecologists. Journal of Nematology 25: $315-331$

Eingegangen: 20.12. 1995 Akzeptiert: 18.09.1996

\title{
Nematoden in der ökotoxikologischen Forschung - Plädoyer für eine vernachlässigte, jedoch sehr aussagekräftige Tiergruppe
}

UWSF 7 (2) 74-83 (1995)

\section{W. Traunspurger, Chr. Steinberg, T. Bongers}

Die ökologische Bedeutung freilebender Nematoden (Fadenwürmer) wird dargestellt und ein ataxonomischer sowie taxonomischer Bioindikationsansatz diskutiert. 